\title{
Poultry Waste Management
}

\author{
Purnima Singh $^{1 *}$, Tanmay Mondal ${ }^{1}$, Rachana Sharma ${ }^{2}$, \\ N. Mahalakshmi ${ }^{1}$ and Mokshta Gupta ${ }^{1}$
}

\author{
${ }^{1}$ Physiology \& Climatology, Indian Veterinary Research Institute, Izatnagar, Bareilly 243122, \\ Uttar Pradesh, India \\ ${ }^{2}$ Dairy cattle physiology Division, ICAR-NDRI, Karnal-132001, Haryana, India
}

*Corresponding author

\section{A B S T R A C T}

\begin{tabular}{|l|}
\hline Ke y w o r d s \\
$\begin{array}{l}\text { Poultry, Pollution, } \\
\text { Mortality and } \\
\text { farming }\end{array}$ \\
\hline Article Info \\
\hline $\begin{array}{l}\text { Accepted: } \\
\text { 06 July 2018 } \\
\text { Available Online: } \\
\text { 10 August } 2018\end{array}$ \\
\hline
\end{tabular}

\begin{abstract}
Poultry industry is one of the fastest growing markets. The poultry industry produces large amounts of solid waste. There are many different waste management options for poultry waste including land application of litter as an organic fertilizer, feed for livestock, biogas production, products for commercial purposes. Poultry wastes are posing serious environmental pollution problems, through offensive odours and promotion of fly and rodent breeding. The appropriate utilization of its waste or by-products increases the monetary output and protects from its unwanted side-effects. Inadequate approach and carelessness of disposal of poultry slaughter house waste products will lead to the constant threat of disease ailments on poultry farms. This results in direct losses in the form of mortality and reduced productivity. Therefore, early disposal of wastes with a wellorganized method is an important poultry waste management tool for raising healthy and profitable poultry farming activity
\end{abstract}

\section{Introduction}

Poultry is one of the fastest growing segments of the agricultural sector in India today. As crop production alone may not solve the food difficulty of the fast growing population of country. The poultry production has been the appropriate answer for fulfillment of requirements of balanced diet. India is now the world's third largest egg producer, fourth largest producer of chicken and fifth in poultry meat production. In India Poultry meat, contributes 47.05 percent of total Meat production. As poultry industry expanding its wings, it's also increasing the challenges to properly manage the waste produced from it. It was stated that if waste must be transported to a disposal site, it must be placed in sealed containers to prevent spillage (Olexa and Goldfarb, 2008). Globally, an excess of $90 \%$ poultry waste is spread on land close to the poultry farms (Moore et al., 1995). The poultry industry produces large amounts of solid waste like bedding material, excreta, feed, feathers, hatchery waste, mortality waste and waste water like faeces, urine, saw dust, remnants of drugs pesticides, disinfection of chicken houses and abattoirs. Poultry manure contains high phosphorus which has positive effect on the growth and productivity of crops. 
It is also effective when combined with mineral phosphorus fertilizer for farm use. The poultry wastes also pose serious environmental pollution problems through offensive odours and promotion of fly and rodent breeding (Adeoye et al., 1994). Therefore appropriate dispose/management of waste is required for minimizing the risk and fetching the better vantage of poultry industry. There are different techniques of management and disposal of poultry waste, to reutilize the nutritions and avoid the risk. In this review different methods have included to emphasize management and disposal of poultry waste.

\section{Management of manure and Litter}

Roeper et al., (2005) stated that a major problem coming along with the poultry production is the manure that needs to be taken care of, avoidance of proper treatment can become risky for environment and humans. Generally, manure refers to faeces and urine produced by animals; it contains organic matter and nutrients, which improve its fertilizer value. Litter is a waste by-product of poultry industry, which consists of feces, bedding materials, wasted feed, and feathers (Chen Z et al., 2014). Dong and Tollner (2003) stated that poultry manure can cause environment related problems such as water, air and land pollution. Ammonia, dimethylamine (DMA), trimethylamine (TMA) are the common odorous compounds from poultry manure, (Nowak et al., 2017) study of genotoxic and cytotoxic activity of these compound in the model chicken cell line $(\mathrm{LMH})$, suggested that these compounds can induce cell death by necrosis and apoptosis. The risk of nutrients, organic material, and pathogens contaminating water bodies and public water supplies will greatly increase if manure is spread adjacent to streams, waterways, and lakes (Coote and Zwerman, 1975). High nitrogen content in the poultry manure gives rise to the problem of nitrate leaching and contamination of ground water which in turn effects sources of drinking water with subsequent impact on the health of human beings particularly children.

\section{Soil amendment}

Application of poultry manure improve water holding capacity of soil and increase lateral water movement, therefore improving irrigation potentiality and decreasing the dryness of soils. It increases the number and diversity of soil microorganisms, particularly in sandy conditions. It is difficult to prescribe any uniform standard but care has to be taken to spread poultry manure thinly on the soil instead of dumping in a heap. Since soil condition also varies widely it is difficult to prescribe any limit. It was evidenced that continuous application of composted and noncomposted poultry manures causes the improvement of physical properties of degraded soil, and subsequently increased the maize grain yields more than the application of poultry biochar and unamended manure (Are et al., 2018).

\section{As fertilizer}

The proper handling and management of manure can augment or replace purchased commercial fertilizers (Tao and Mancl, 2008). Utilization of poultry waste as a source of manure for crop production has been the favored system for recycling nutrients. The approximated percentages of nutrient intake excreted by poultry are nitrogen $(65.5 \%)$, potassium $(83.5 \%)$ and phosphorus $(68.5 \%)$, it is beneficial increased crop production (Olumayowa and Abiodun, 2011). Other elements such as calcium, magnesium, sulfur, boron, molybdenum, cobalt, copper, iron, manganese and zinc which are deficient in commercial fertilizer are also there in poultry manure in appreciable amounts. The manure is stored in most of the farms before disposal, at 
least for a period of one month and this leads to loss of nearly $40 \% \mathrm{~N}$ which reduces the value of the manure. In one study chicken manure was added for sweet potato culture and it was suggested that small-scale farmers should avoid use of high levels of chicken manure because higher levels of manure would increase vegetative growth at the expense of tuber formation (Magagula et al., 2010).

\section{Livestock feeding}

Poultry litter has been used in diets for poultry, lambs, ewes, swine, lactating cows, wintering cattle and brood cows. Poultry litter/manure is used as livestock feed in other countries also including Israel and some states in the US (Smith and Wheeler, 1979). Drying of poultry manure is perhaps the oldest procedure of processing waste for refeeding. It was stated that amino acid nitrogen of cage layer waste ranges from 37 to $40 \%$ of total nitrogen and that about 40 to $60 \%$ of total nitrogen in poultry excreta is present in the form of non-protein nitrogen (NPN) (Chaudhry et al., 1997). When it is given to ruminants as feed, uric acid which is the major NPN source in poultry is degraded to ammonia by rumen microbes. The maximum inclusion rate of poultry waste in ruminant feeds is 20\% [National Research Council (NRC) (1984)]. Adding broiler litter into beef cattle rations at a level of $20 \%$ or higher (as fed basis) can satisfy crude protein, calcium and phosphorus requirement (Crickenberger and Goode, 1996). The investigators reported addition of poultry litter at a level of $30 \%$ into corn silage has beneficiary effect. Dried poultry waste contains $28 \%$ protein and $30 \%$ ash and is also an excellent source of calcium, phosphorus, potassium, iron and zinc (NRC, 1984). It was studied that poultry waste fed at levels above $35 \%$ usually covers almost the total protein requirement of sheep, and contributes substantially to the energy of the total ration (Muller, 1980). It was also noted that high copper level in poultry diet can cause toxicity in sheep. (Chaudhry et al., 1997) argued that the feeding poultry waste to livestock can cause health hazards like pathogens and residues of pesticides. Also there may be problems associated with nutrient loss mainly through volatilisation of ammonia (Caswell et al., 1975). It is suggested that ensiling poultry waste, i.e. slaughterhouse wastes with molasses and lactobacilli improves NPN and reduces pathogens. Because material may be a potential source of pathogenic bacteria (e.g. Salmonella), moulds and yeasts (Alexander et al., 1968), feeding of poultry waste depends on the type and standard of management of the birds.

\section{Drying of poultry manure}

Drying in natural air conditions under sunlight is one of the most economical and feasible methods for tropical countries like India. Poultry waste has high water content, there is a need to develop a proper and inexpensive processing technology to remove excessive moisture and destroy harmful pathogens from the organic waste. Moreover, fresh poultry droppings have lower moisture content than manure from other livestock, making sun drying the most effective processing method. Dried poultry waste reportedly contains about 30 per cent protein, of which about 60 per cent is from non-protein nitrogenous sources. Drying is affected by several factors which alter its property (Ghaly and Alhattab et al., 2013) Thin layer $(1-3 \mathrm{~cm})$ drying of poultry manure is effective at temperatures within the range provided by solar heaters $\left(40-60^{\circ} \mathrm{C}\right)$. Greater nitrogen losses (44-55 \%) is observed at the deeper manure layer and higher temperature which resulted in a reduction in $\mathrm{N}: \mathrm{P}: \mathrm{K}$ from the initial value of $4.58: 1.29: 1$ to final values in the range 2.07:1.30:1$2.57: 1.28: 1$. Drying is helpful in reducing the 
presence and offensiveness of odor by 65.3 and $69.3 \%$, respectively, reduction in bacteria (65.6-99.8\%), yeast and mold (74.1-99.6\%) and E. coli (99.97\%). Dried poultry manure has high nitrogen, phosphorus and potassium contents which are essential for plant growth.

\section{Bioenergy production}

Poultry manure and litter is rich in organic matter which can be transforming into bioenergy. Water flushing is one of the common processes for bioenergy production. In this technique, manure is digested anaerobically that produces a gas mixture with varying concentrations of combustible methane (FAO/CMS, 1996). Biogas is a source of energy; it can be used as a fuel for engines, generation of electricity and other energy consuming purposes. Anaerobically processed products are very much acceptable for land treatment and feed supplement. This technique is not much popular yet as it is costly, need operational feasibility and produce less biogas from poultry litter system.

\section{Management of feathers}

Feathers are also used in animal feed, organic fertilizers and feed supplements, as it is made up of $>90 \%$ protein and is rich in cystine, arginine and threonine as they are hydrophobic amino acids, can resist from hydrothermal process that makes feather more digestible (Ekta and Rani, 2012). A slow release nitrogen fertilizer has been developed from poultry feathers (Jong-Myung Choi and Paul V. Nelson, 1996). It was reported that the feather-lysate produced by Bacillus licheniformis PWD-1 has nutritional property for feed similar to soybean protein. For minimizing environmental hazard new techniques are constructed for the production of biodiesel from feather meal (Thyagarajan et al., 2013). The nonwoven textile materials prepared by chicken feathers are very versatile and have a wide application in the field of technical textiles (Chinta et al., 2013). Poultry feathers are also converted into biodegradable plastics by a process called polymerization. In this process, feathers which contain keratin protein are pulverized into fine dust.

\section{Management of poultry offal}

Poultry offals are solid by-products, wastes of poultry slaughterhouse or poultry processing plant. It includes parts and/or whole poultry carcass, undeveloped eggs, waste produced in broiler farming and slaughter house. Offal consists of $5.3 \%$ of total Kjeldahl nitrogen, $32 \%$ proteins, $54 \%$ lipids and 0.6 to $0.9 \%$ methane production potential (Salminen and Rintala, 2002). According to one study, significantly $(\mathrm{P}<0.05)$ higher body weight, as well as, better feed conversion ratios were found in poults fed diets with $25 \%$ poultry waste carcass meal crude protein replacement, compared with diets containing only fishmeal as a protein source (Santhi et al., 2011).

The investigators concluded that levels of poultry waste carcass meal replacing the crude protein from fishmeal up to $25 \%$ appeared acceptable based upon eighth-week body weight and feed efficiency.

\section{Poultry waste disposal methods}

The disposal of poultry carcasses is a serious trouble for poultry industry, as it has environmental, biological, and financial concern (Cai et al., 1994). The carcasses may not be disposed of by dumping on any public road or right-of-way left where they may be consumed by animals (Olexa and Goldfarb, 2008). Worldwide, there are several ways of disposing of poultry waste including; burial, rendering, incineration, compositing, feed for livestock, fertilizer or source of energy. Each disposal option has advantages and disadvantages. 
Int.J.Curr.Microbiol.App.Sci (2018) 7(8): 701-712

\section{Poultry industry}

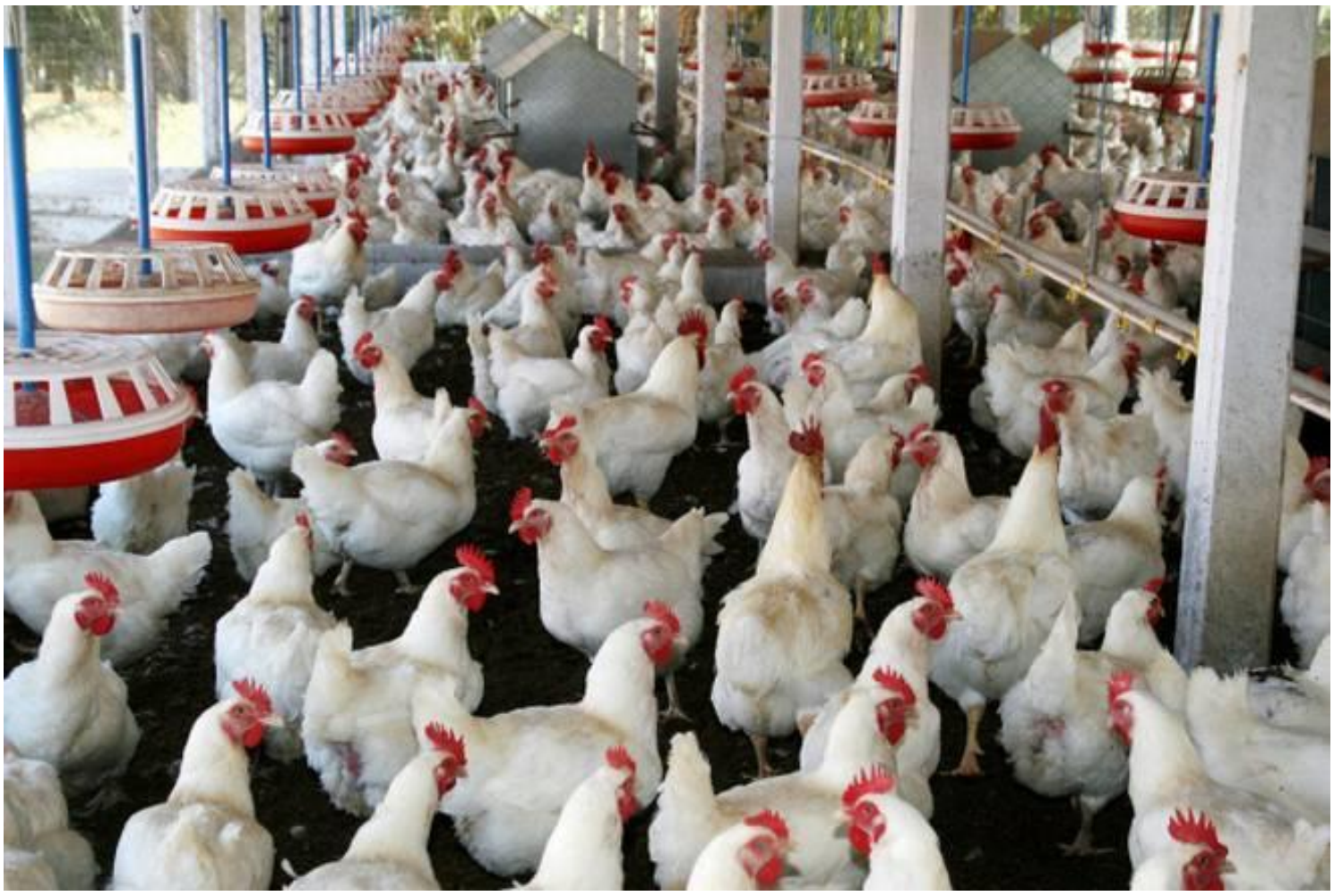

Soil amendment

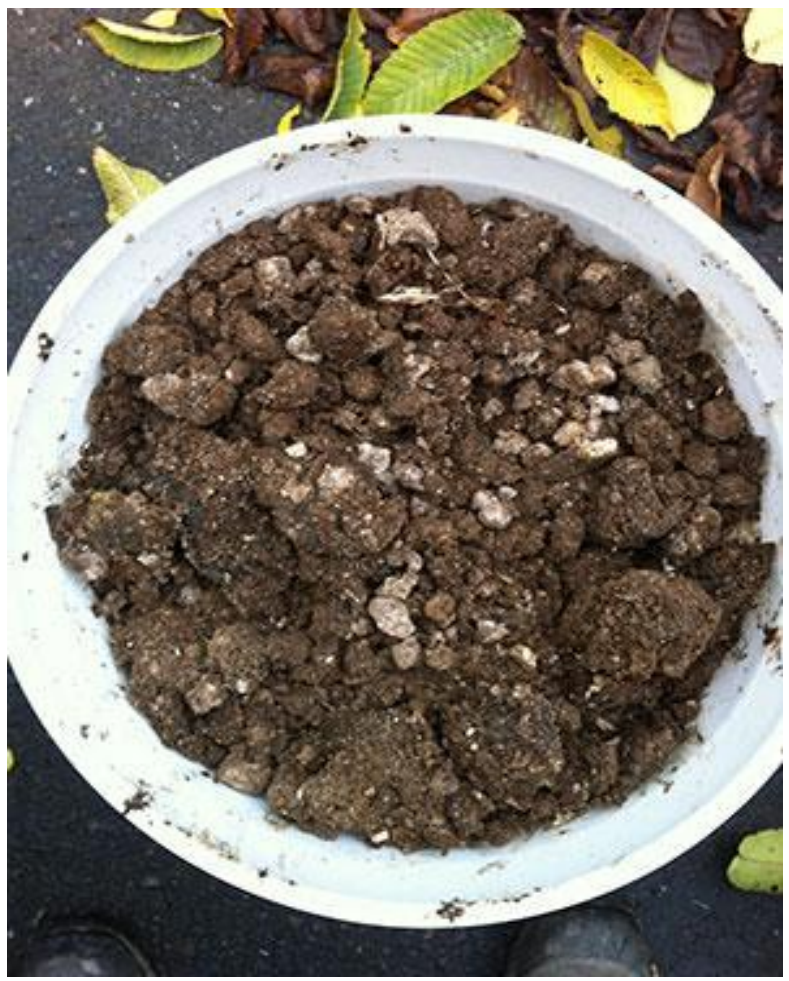




\section{Burial}

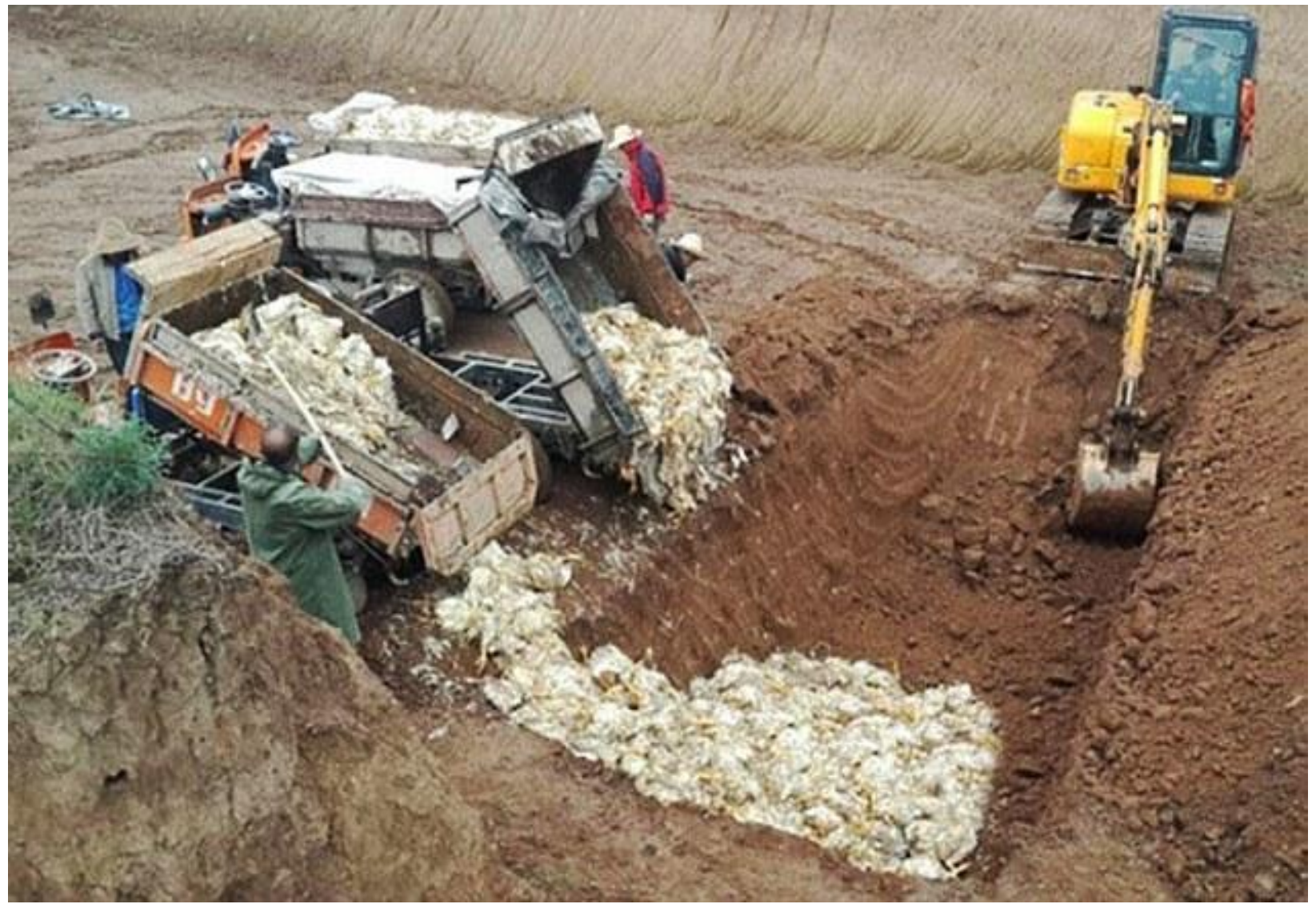

\section{Compositing}

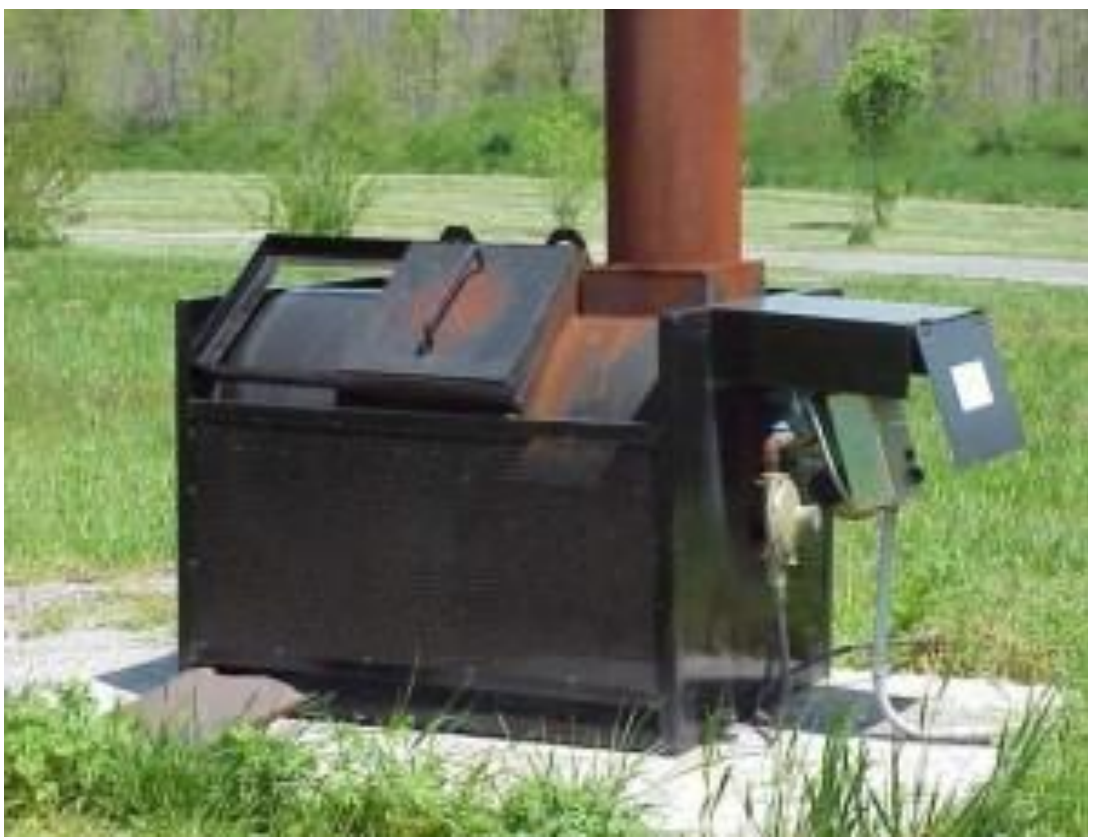




\section{Poultry waste disposal methods}

\begin{tabular}{|c|c|c|c|}
\hline Serial no. & Method & Advantage & Disadvantage \\
\hline 1. & Burial & $\begin{array}{l}\text { - Predominant disposal } \\
\text { option for catastrophic mortality } \\
\text { events or infectious outbreaks } \\
\text { - } \quad \text { Simplest and economical } \\
\text { methods } \\
\text { - Safe method }\end{array}$ & $\begin{array}{l}\text { The poor site selection, such } \\
\text { as sandy soils or areas with high } \\
\text { water tables, may pose a threat to } \\
\text { groundwater }\end{array}$ \\
\hline 2. & Burning & - $\quad$ Easy and economic & - $\quad$ Atmospheric pollution \\
\hline 3. & Incineration & $\begin{array}{l}\text { - Most effective methods } \\
\text { for destroying potentially } \\
\text { infectious agents } \\
\text { - Eliminating the threat of } \\
\text { disease } \\
\text { - The residue is mostly } \\
\text { harmless and does not attract } \\
\text { rodents or insects }\end{array}$ & $\begin{array}{l}\text { The air emission, process } \\
\text { conditions, and the disposal of solid } \\
\text { and liquid residues need to be } \\
\text { strictly controlled } \\
\text { - It requires proper sources of } \\
\text { fuel and supervision, otherwise } \\
\text { smoke and odour can create } \\
\text { nuisance complaints. } \\
\text { - Expensive method }\end{array}$ \\
\hline 4. & Compositing & $\begin{array}{l}\text { - Resultant products are } \\
\text { much more environmentally } \\
\text { acceptable than raw litter for } \\
\text { land application } \\
\text { - } \quad \text { Economic method } \\
\text { Kill pathogens, control } \\
\text { disease outbreaks. } \\
\text { - Reduces the risk of } \\
\text { nitrogen and phosphorus } \\
\text { entering the water systems }\end{array}$ & $\begin{array}{l}\text { - Loss of nutrients like } \\
\text { nitrogen. } \\
\text { - Land area required for the } \\
\text { compositing } \\
\text { Odour problems } \\
\text { - } \quad \text { Emission of greenhouse } \\
\text { gases such as methane and nitrous } \\
\text { oxide }\end{array}$ \\
\hline 5. & Rendering & $\begin{array}{l}\text { Rendering products can } \\
\text { be used as feed, fertilizer } \\
\text { - Fat product can be used } \\
\text { for soaps, washing powders, } \\
\text { cosmetics, fuel. }\end{array}$ & $\begin{array}{l}\text { Emission of gas and odour } \\
\text { leads environment concern }\end{array}$ \\
\hline
\end{tabular}

\section{Burial}

Besides burning and rendering, the carcasses of dead domestic animals may be disposed of by burial. According to (Malone, 2005), onfarm burial has been the predominant disposal option for many catastrophic mortality events such as avian influenza outbreaks. It was suggested (Anon, 2005) that for mass disposal of animals (poultry, swine, and calves) burial pits can be used if they are designed, constructed, maintained, and used in a manner to prevent the spread of diseases. Burial is one of the simplest and most cost-effective methods employed to deal with many types of mass mortality losses. However, burial of dead birds in a pit can lead to ground water contamination (Cai et al., 1994) and public perception concerns if not properly managed. Payne mentioned that when proper guidelines 
are followed, burial is a safe option but that poor site selection, such as sandy soils or areas with high water tables, may pose a threat to groundwater. Previous work (Payne) indicated that burial of mortality requires the construction of a pit, which must be located at least $91.44 \mathrm{~m}$ away from any wells, waters of the state, neighboring residences, public areas or property lines. The bottom of the burial pit must be at least $30.48 \mathrm{~cm}$ above any floodplain level and at least $60.96 \mathrm{~cm}$ above the seasonal-high water table. On the other hand, Anon (2005) indicated that mortality to be buried must be located more than $30.48 \mathrm{~m}$ away from any existing or proposed wells, water supply lines, or seasonable high water table of any water source, and $4.57 \mathrm{~m}$ horizontal away from the edge of any embankment. Additionally, burial sites must not be in areas with gullies, ravines, dry streambeds, natural or man-made drainage ways or sinkholes. Payne stated that if there is bedrock in the area, the bottom of the pit must be at least $60.96 \mathrm{~cm}$ above the bedrock. In addition, carcasses must be covered with a minimum of $76.2 \mathrm{~cm}$ of top soil after placement in the pit. Anon (2005) stated that mortality must be buried at least $0.91 \mathrm{~m}$ below ground level but no more than $2.44 \mathrm{~m}$ deep. Animals may be buried in mass burial pits or in approved landfills. The soil for a burial site must be of moderate or slow permeability and must be at least one 30.48 $\mathrm{cm}$ above the seasonal high groundwater elevation.

\section{Burning}

This is one of the common methods of disposing, especially among small-scale farmers. In this disposal method, mortalities are fully burned at relatively high temperatures using fuels such as wood, tyres or diesel. However, this waste disposal method may lead to atmospheric pollution in the event of catastrophic mortalities resulting from outbreaks of highly infectious diseases such as Newcastle disease and avian influenza. Anon (2005) argued that burning is not a preferred method of disposal because of the resulting air pollutants. Incomplete carcass combustion leads emission of Dioxins and furans, they are carcinogens and can negatively affect human reproduction, development and immune systems (Rier, 2008). According to Anon (2005), mass cremation of mortality should be performed in a flat area that is easily accessible to heavy vehicles for transporting the carcasses and away from public view. The site must be located away from buildings, public roads, and overhead electric and telephone lines, underground utility wires, and shallow underground pipes or gas lines.

\section{Incineration}

Incineration is recognized as one of the biologically safest methods of disposal, eliminating the threat of disease (Blake et al., 2008). Incineration refers to process of thermal destruction, apparently among the most effective methods for destroying potentially infectious agents (Ritter and Chinside, 1995). The major concern during incineration is, the air emission, process conditions, and the disposal of solid and liquid residues need to be strictly controlled. The residue from properly incinerated mortality is largely harmless and does not attract rodents or insects. Payne stated that incineration eliminates all pathogens but has high operational costs and if not properly conducted it can contribute to air pollution that decreases its usefulness for widespread use as a mortality carcass disposal option. Malone (2005) argued that the incineration process is slow, loading decomposed carcass poses a problem and it will require disposal of 0.3 tonnes of ash per tonne of carcass. It requires proper sources of fuel and supervision of the process, otherwise smoke 
and odour can create nuisance complaints. It has been reported that incineration is expensive and can potentially pollute the air (Cai et al., 1994). Therefore, incineration not much recommended for large-scale poultry operations that produce large amounts of mortalities but beneficial for poultry slaughter facilities.

\section{Compositing}

Composting is a natural, biological process by which organic material is broken down and decomposed (Malone, 2004). This process is carried out by successive microbial populations which function under increasing temperatures to break down organic materials into carbon dioxide, water, minerals, and stabilized organic matter (Evanylo et al., 2009). However, wastes having high moisture with low fibre content need higher amounts of moisture-sorbing and structural support to compost well (Tritt and Schuchardt, 1992). It is a biological process in which organic wastes are converted into products which can be potentially used as soil conditioner and organic fertilizer (Brake, 1992). According to Malone (2005), microorganisms will rapidly compost carcasses in the presence of oxygen $(>5 \%)$, moisture (40-60\%), and a proper carbon to nitrogen ratio $(20: 1$ to $35: 1)$. This process produces carbon dioxide, water vapour, heat and compost. It takes 2 to 6 months for the animal to decompose (Anon, 2002). The benefits of compositing are manifold. Compositing has the ability to reduce poultry litter, dispose of carcasses, stabilise trace minerals and reduce odours (Turnell et al., 2007; Bonhotal et al., 2008). It can be done any time of the year and can be done with equipment available on farms; hence it is economical (Bonhotal et al., 2008). The most efficient temperature range for composting is between $40{ }^{\circ} \mathrm{C}$ and $60{ }^{\circ} \mathrm{C}$. However, compost pile temperatures are dependent on the amount of heat produced by the microorganisms that is lost through aeration or surface cooling. In the opinion of Turnell et al., (2007), the immobilisation of nitrogen and phosphorus during compositing reduces the risk of these nutrients entering the water systems. Furthermore, compositing reduces the pathogenic organisms due to the high heat produced during the process of compositing. Das et al., (2002) reported that hatchery waste compositing reduces $\mathrm{E}$. coli and salmonella by $99.9 \%$ and $100 \%$, respectively. The disadvantages of compositing are loss of some nutrients including nitrogen, the land area required for the compositing and odour problems (Glatz et al., 2011). A potential problem with compositing is the emission of greenhouse gases such as methane and nitrous oxide, which are efficient in absorbing infra-red radiation resulting in global warming and acid rain. Animal production contributes $7 \%$ of greenhouse emissions worldwide through the decomposition and degradation of manure (Hao et al., 2004).

\section{Rendering}

Rendering is a process of application of heat to remove fat from meat (Swan, 1992). It is much suited for high-risk material disposal. Rendering products can be used in animal feed, as fertiliser or further processed via anaerobic digestion or composting. Materials are exposed to $133^{\circ} \mathrm{C}$ temperature for a minimum of $20 \mathrm{~min}$ at 3 bars or an alternative heat treatment, to make it suitable for fertilizing and feeding purposes. Heat treatment also increases the storage time of resultant products by removing moisture and killing microorganisms (NABC, 2004 Carcass Disposal). Rendered feed product can be used for chemical industry or energy source in the form of fuel. Slaughterhouse by-products are preserved with formic acid as it has a good source of proteins and vitamins and is used as animal feed (Pulsa, 1996). The legislation, 
however, has become stringent about the use of slaughter by-products for animal feed to reduce the risk of disease transmission via the feed and the food chain. The main environmental concerns associated with rendering are gas and odour emissions (DEFRA, 2008)

Poultry waste management is difficult and challenging, because of its linked problems, like nitrate and heavy metal contamination in crops, soil, water, air quality and odor; disposal of dead and diseased poultry and food safety. Slaughter house wastes like feathers, blood, and innards are being processed and utilized as high-protein animal feed sources or as fertilizer due to its high nitrogen content. Poultry farming in India, in spite of several challenges, has progressed drastically. Poultry industry contributes an vital role in economy of nation as well as improving the standard of living of people. The proper utilization and disposal of poultry sector will not only helping this industry but also avoiding the unnecessary discomfort to living beings and environment. The decomposition of the waste must be done with proper handing and care to avoid any risk of disease outbreak and to prevent environment pollution

\section{References}

Adeoye, G. O., Sridhar, M. K. C., and Mohammed, O. E. (1994). Poultry waste management for crop production: Nigerian experience. Waste management and research, 12(2), 165172.

Alexander, D. C., Carrière, J. A., and McKay, K. A. (1968). Bacteriological studies of poultry litter fed to livestock. The Canadian Veterinary Journal, 9(6), 127.

Anon (2005).Management of animal mortality in Georgia. January 2005.
Are, K.S., AO Adelana, IOO Fademi, OA Aina (2017). Improving physical properties of degraded soil: Potential of poultry manure and biochar. Agriculture and Natural Resources. Volume 51, Issue 6, December 2017, Pages 454-462

Blake, J.P., J.B. Carey, A.K.M. Haque, G.W. Malone, P.H. Patterson, N.L. Tablante, and N.G. Zimmermann. Poultry carcass disposal options for routine and catastrophic mortality. Council for Agricultural Science and Technology (CAST) Issue Paper No. 40, October 2008.

Bonhotal, J., Schwarz, M., and Brown, N. (2008). Natural Rendering: Composting Poultry Mortality. The Emergency Response to Disease Control.Fact sheet.

Brake, J. D. (1992).A practical guide for composting poultry litter. BulletinMississippi Agricultural and Forestry Experiment Station (USA).

Cai, T., Pancorbo, O. C., Merka, W. C., Sander, J. E., and Barnhart, H. M. (1994). Stabilization of poultry processing by-products and waste and poultry carcasses through lactic acid fermentation. Journal of Applied Poultry Research, 3(1), 17-25.

Chaudhry, S. M., Naseer, Z., and Alkraidees, M. S. (1997). Nutritive evaluation of poultry waste and sudex grass silage for sheep. ASIAN AUSTRALASIAN JOURNAL OF ANIMAL SCIENCES, 10, 79-85.

Chen, Z., and Jiang, X. (2014). Microbiological safety of chicken litter or chicken litter-based organic fertilizers: a review. Agriculture, 4(1), 1-29.

Chinta, S. K., Landage, S. M., and Yadav, K. (2013).Application of chicken feathers in technical textiles. International Journal of Innovative Research in Science, Engineering and Technology, 2(4), 1158-1165. 
Choi, J. M., and Nelson, P. V. (1996). Developing a slow-release nitrogen fertilizer from organic sources: II. Using poultry feathers. Journal of the American Society for Horticultural Science, 121(4), 634-638.

Coote DR and Zwerman, PJ (1975). Manure disposal, pollution control, and the New York Dairy Farmer. New York's Food and Life Sciences Bulletin No. 51, April 1975.

Crickenberger RG and Goode L (1996). Guidelines for feeding broiler litter to beef cattle. North Carolina Cooperative Extension Service. North Carolina State University.

Das KC, Minkara MY, Melear ND and Tollner EW (2002). Effect of poultry litter amendment on hatchery waste compositing. Journal of Applied Poultry Research, 11: 282-290.

DEFRA (2008) Consultation on 1.1.1 Sector Guidance Note IPPC SG8: Integrated Pollution Prevention and Control (IPPC), Secretary of State's Guidance for the A2 Rendering Sector. DEFRA Publications, UK.

Dong, X., and Tollner, E. W. (2003). Evaluation of Anammox and denitrification during anaerobic digestion of poultry manure. Bioresource Technology, 86(2), 139145.

Evanylo, G. K., Sherony, C. A., May, J., Simpson, T. W., and Christian, A. H. (2009). The Virginia Yard Waste Management Manual.

FAO/CMS. (1996). Biogas technology: a training manual for extension.

Ghaly, A. E., and Alhattab, M. (2013). Drying poultry manure for pollution potential reduction and production of organic fertilizer. American Journal of Environmental Sciences, 9(2), 88.

Glatz, P., Miao, Z., and Rodda, B. (2011). Handling and treatment of poultry hatchery waste: A review. Sustainability, 3(1), 216-237.

Haar, L. (1984). NBS/NRC steam tables. CRC Press.

Hao X, Chang C. and Larney FJ (2004). Carbon, nitrogen balances and greenhouse gas emission during cattle feedlot, manure compositing. Journal of Environmental Quality, 33: 37-44.

Magagula, N. E. M., Ossom, E. M., Rhykerd, R. L., and Rhykerd, C. L. (2010). Effect of chicken manure on soil properties under sweet potato (Ipomoea batatas (L.) Lam) culture in Swaziland. American-Eurasian Journal of Agronomy, 3(2), 36-43.

Malone B (2004). Compositing poultry losses. Proceedings 2004 Poultry Information Exchange. Surfers Paradise, Queensland., Australia. April 19, 2004. Pp. 39-42.

Malone, G. (2005) Catastrophic mortality management. In Proceedings of the 2005 Pennsylvania Poultry Sales and Service Conference, Grantville, PA.

Moore, P. A., Daniel, T. C., Sharpley, A. N., and Wood, C. W. (1995). Poultry manure management: Environmentally sound options. Journal of soil and water conservation, 50(3), 321-327.

Müller ZO (1980). Feed from animal wastes: state of knowledge. FAO Animal Production and Health Paper 18.Food and Agriculture Organization of the United Nations.

NABC (2004) Carcass Disposal: a Comprehensive Review. Report Written for the USDA Animal and Plant Health Inspection Service, National Agricultural Biosecurity Centre, Kansas State University, USA.

Nowak, A., Bakuła, T., Matusiak, K., Gałęcki, R., Borowski, S., and Gutarowska, B. (2017). Odorous Compounds from Poultry Manure Induce DNA Damage, Nuclear 
Changes, and Decrease Cell Membrane Integrity in Chicken Liver Hepatocellular Carcinoma Cells. International journal of environmental research and public health, 14(8), 933.

Olexa MT and Goldfarb I (2008). Hazardous waste regulation: Biological and animal waste disposal. Food and Resource Economics Department, Florida Cooperative Extension Service, Institute of Food and Agricultural Sciences, University of Florida, Gainesville, FL

Olumayowa, O., OO Abiodun (2011). Profit efficiency and waste management in poultry farming: the case of Egba Division, Ogun State, Nigeria. International journal of poultry science.

Parthasarathy, M., and Pradhan, K. (1982). Fermentation characteristics and feeding value of ensiled poultry litter containing wheat straw, bagasse or sawdust. Animal Feed Science and Technology, 7(4), 341-349.

Pulsa, A.

(1996).

Turkistarhattarvitsevatlaadukastateurasj äatettäa. Lihalehti 3, 38-41.

Rier, S. E. (2008). Environmental immune disruption: a comorbidity factor for reproduction? Fertility and sterility, 89(2), e103-e108.

Ritter, W. F., and Chirnside, A. E. M. (1995).Impact of dead bird disposal pits on ground-water quality on the Delmarva Peninsula. Bioresource Technology, 53(2), 105-111.

Roeper, H., Khan, S., Koerner, I., and Stegmann, R. (2005, October). Lowtech options for chicken manure treatment and application possibilities in agriculture. In Proceedings Sardinia, Tenth International Waste Management and Landfill Symposium (pp. 3-7).

Salminen, E., and Rintala, J. (2002). Anaerobic digestion of organic solid poultry slaughterhouse waste-a review. Bioresource technology, 83(1), 13-26.

Santhi, D., Sundaresan, A., Thyagarajan, D., and Kulkarni, V. V. (2011). Utilization of poultry whole carcass meal in diets for turkey poults. Global Veterinaria, 6(1), 106-110.

Smith, L. W., and Wheeler, W. E. (1979). Nutritional and Economic Value of Animal Excreta 1. Journal of Animal Science, 48(1), 144-156.

Swan, J.E. (1992). Animal by-product processing. Y.H. Hui (Ed.), Encyclopedia Food Science Technology, 4: pp. 42-49

Tao J and Mancl K (2008). Estimating manure production, storage size, and land application area. Fact Sheet Agriculture and Natural Resources AEX-715-08, The Ohio State University Extension.

Tritt, W. P., and Schuchardt, F. (1992). Materials flow and possibilities of treating liquid and solid wastes from slaughterhouses in Germany. A review. Bioresource Technology, 41(3), 235245.

Turnell, J. R., Faulkner, R. D., and Hinch, G. N. (2007). Recent advances in Australian broiler litter utilisation. World's poultry science journal, 63(2), 223-231.

\section{How to cite this article:}

Purnima Singh, Tanmay Mondal, Rachana Sharma, N. Mahalakshmi and Mokshta Gupta. 2018. Poultry Waste Management. Int.J.Curr.Microbiol.App.Sci. 7(08): 701-712. doi: https://doi.org/10.20546/ijcmas.2018.708.077 